\title{
O governo de J uscelino Kubitschek e o mito da democracia representativa: a vigilância do Serviço Secreto do DOPS-SP nas agremiações democráticas 1956-1960*
}

\author{
The J uscelino Kubitschek government and the representative \\ democracy myth: the vigilance of the DOPS-SP Secret Service in the \\ democratic associations in 1956-1960
}

Nilo Dias de Oliveira**

RESUMO

O presente artigo tem como objetivo analisar a prática de vigilância e repressão do Serviço Secreto da DOPS-SP através da análise dos seus relatórios durante o período de 1956 1960, dando ênfase à ação deste órgão sob alguns movimentos reivindicatórios que vislumbravam nesses novos tempos de grandes transformações na sociedade brasileira, propostas de mudanças efetivas na relação entre o capital e o trabalho. A infiltração de seus agentes nestas agremiações demonstra a vinculação deste sistema repressivo com os segmentos políticos subordinados aos setores das burguesias dependentes, cujo monopólio de dominação se via ameaçado pela ampliação dos direitos civis.

PALAVRAS-CHAVE: Serviço Secreto. DOPS-SP. Classe Operária. Partido Comunista do Brasil

\section{ABSTRACT}

The present article has the objective of analyzing the monitoring and the repressing practices of the Secret Service of the DOPS-SP through the analysis of its reports during the period of $1956-1960$, giving emphasis to the action of this agency under some vindication movements that glimpsed in these new times of great transformations in the Brazilian society, proposals of effective changes in the relation between the capital and the work. The infiltration of its agents in these associations demonstrates the entailing of this repressive system with the politicians segments subordinated to the sectors of the dependent bourgeoisies, whose monopoly of domination was threatened by the magnifying of the civil rights.

Keywords: Secret service. DOPS-SP. Working Class. Communist Party of Brazil

\section{Partidos, Nacionalismos e Interesses de Classe}

O governo de Juscelino Kubitschek antes mesmo de seu inicio enfrentou uma série de dificuldades, as adversidades políticas que marcaram o período entre sua indicação como candidato e sua posse como presidente não deixavam dúvidas quanto à ferrenha oposição que seu governo, fruto da aliança PSD-PTB, teria pela frente,

\footnotetext{
* Este artigo é parte modificada de minha dissertação de mestrado intitulada A vigilância do DOPSSP às Forças Armadas (Brasil década de 50) sistema repressivo num Estado de natureza autocrática, orientada pela Prof ${ }^{a}$ Dra a Vera Lucia Vieira, Pontifícia Universidade Católica de São Paulo, PUC-SP, 2008 com apoio da CAPES.

** Doutorando em História Social pela PUC-SP. nilodiasoliveira@gmail.com
} 
particularmente pela oposição udenista. Estes e os militares da Escola Superior de Guerra (ESG) encaravam o novo governo como uma herança daquilo que eles mais temiam do governo de Getulio Vargas: considerava J uscelino e J ango uma "aposta" perigosa devido a sua aproximação com os trabalhadores e membros do PCB.

Apesar disso, e das tentativas efetivas de derrubada do governo após a posse de $\mathrm{JK}^{1}$, os segmentos da burguesia que se aglutina na UDN e seus aliados políticos, não foram capazes de anular a forte composição partidária representada pelo PSD/PTB. Analisada apenas por suas posições políticas, as posições da UDN e do udenismo se manifestam contraditórios e neste sentido temos como exemplo, as conclusões de pesquisadores do CPDOC segundo os quais,

Contradições e cisões acompanharam a trajetória udenista. Coexistiram na UDN teses liberais e autoritárias, progressistas e conservadoras. O partido que vota a favor do monopólio estatal do petróleo (1953) e contra a cassação dos mandatos dos parlamentares comunistas (1947) é o mesmo que se opõe à intervenção do Estado na economia, denuncia a "infiltração comunista" na vida pública e contesta os resultados quando perde as eleições. O partido ficou marcado pela vinculação com os militares e as aspirações das camadas médias urbanas, identificando-se, também extrapartidariamente, com o udenismo. (BENEVIDES, 2000, p.1).

No entanto, visto do ponto de vista do desenvolvimento do capitalismo, as posições dos segmentos da classe burguesa que compõem a UDN se manifestam bem coerentes, pois se por um lado, contrapõe-se ao projeto de crescimento industrial por substituição de importações, por outro se aliam ao capital transnacional que se instala maciçamente, enquanto chamavam a atenção para os custos sociais envolvidos na proteção da indústria nacional e questionavam as ligações perigosas entre políticos, empresários e operários manuais.

Seu conservadorismo se manifesta pela impossibilidade de partilhar com segmentos populares organizados o poder político e ante esta necessidade, posta pelo próprio estágio de desenvolvimento do capitalismo no país, aciona as Forças Armadas cujos líderes articulados na ESG também saem em defesa do capital internacional como única forma de romper com o subdesenvolvimento. Assim este segmento apóia as teses liberais de ampliação da democracia e do Estado protecionista - daí seu apoio inicial à manutenção do petróleo estatizado e seu voto contra a cassação do mandato dos parlamentares comunistas, ao mesmo tempo em que articula os golpes militares ante a expectativa de perda do monopólio do poder.

\footnotetext{
${ }^{1}$ Conforme afirma J osé Murilo de Carvalho , a candidatura de Juscelino Kubitschek, lançada pelo Partido Social Democrático (PSD), reacendeu o udenismo militar, pois os mesmos que combatiam Vargas passaram a combater Juscelino que o acusavam de continuador do varguismo. Eles levantaram a tese da exigência de maioria absoluta de votos na eleição presidencial de 1955.
} 
Percebe-se aqui que sua plataforma obstrucionista aos projetos "desenvolvimentistas" na esfera de política cambial (que favoreciam a implantação da indústria no país), prejudicava seus interesses econômicos (importadores, latifundiários) e os colocava fora como grupo hegemônico.

Na mesma medida, o PSD articulava os antigos interventores do "Estado Novo", comerciantes, advogados, proprietários rurais², o que não os diferenciava muito da UDN. Assim os dois partidos, apesar das especificidades políticas, representavam interesses da pequena e média burguesia, que divididas por suas influências "ideológicas regionais", explicitam o liberalismo conservador na condução da política nacional e que naquele momento vê-se ante a ameaça de uma ampliação das bases que compõem o poder político; Tal ameaça se expressava na aglutinação social que compunha o PTB, que segundo Benevides,

\begin{abstract}
teve suas origens estreitamente ligadas ao "movimento queremista", (e que) surge como uma tentativa de aglutinar as novas forças sociais, nascidas do impulso econômico pela industrialização, visando atingir fundamentalmente os operários urbanos frente à ameaça que constituía a influência do Partido Comunista, não apenas sobre a massa trabalhadora desorganizada, mas, sobretudo os sindicatos. (BENEVIDES. 1979, p. 63).
\end{abstract}

Assim compunha-se a correlação de forças sociais que se expressava no tripé partidário político mais significativo do período J K (e também do período getulista) e a agenda política implantada por eles (a prioridade de aprovação ou obstrução dos projetos governamentais na câmara e no senado federal), demonstra a disputa entre os interesses do capital internacional e os dos grupos regionais dominantes. A ameaça ao bloco dominante estava não apenas na sua fragilidade ante esta divergência no interior de sua composição e que já vinha se manifestando desde a década de 30, mas na entrada em cena dos segmentos que representavam interesses corporativos dos trabalhadores, também frágeis por sua emergência no interior do capitalismo hiper tardio, aos quais se mesclavam setores das classes médias urbanas.

Nesta correlação de forças o termo nacionalismo é tomado em vários sentidos, aparentemente contraditório se visto do ponto de vista apenas político. Pois todos lhe atribuem uma universalidade inexistente, já que não há a defesa da nação, sequer a defesa dos interesses de classe, dado que nas condições de desenvolvimento do capitalismo no Brasil, observa-se de fato, a defesa dos interesses privados que se aglutinam formando forças mais ou menos coesas que, por um lado, defendem a manutenção do status quo e ou disputam espaços nesta mesma ordem política. Não por

2 Na relação coronel-Estado o PSD era a instituição intermediária, canalizador dos votos e distribuidor dos cargos. 
acaso não surge um projeto alternativo do interior de nenhum destes segmentos que disputam o poder político, capaz de promover qualquer alteração significativa na condução do desenvolvimento do país.

Assim, se por um lado se fazia premente superar os problemas de infraestrutura para o desenvolvimento industrial nas mesmas bases monopolistas vigentes desde sempre, o que punha a necessidade de capitais que financiassem tais investimentos, por outro, as demandas dos segmentos urbanos e os tradicionais interesses das burguesias agrárias regionais, pressionavam pela partilha destes mesmos capitais, mas para usos cujos interesses confrontavam os do capital monopolista dependente.

Daí que as divergências ficam restritas ao âmbito político-ideológico e se concentram na condução do processo de abertura política como expressão em última instância uma ameaça aos interesses das classes dominantes (burguesia industrial e proprietários rurais que também compõem a base de governo), configurando-se o politicismo tão apropriadamente anotado por Chasin (2000, p.127).

Determinada, histórica e estruturalmente, a ficar muito aquém dos limites mais ricos e amplos das entificações burguesas clássicas e até mesmo prussianas, desconhece a autonomia econômica e lhe é completamente estranho o encargo de universalizante político - não pode se ver e assumir, na particularidade de seus interesses, como representante de todas as categorias sociais, da sociedade em seu conjunto. Vedados lhe são o luxo' e o simulacro dessa representação, mesmo na forma de pretensão clássica, dado que se encontra sempre, pela sua atrofia estrutural e pela época em que surge e se manifesta em seus desdobramentos, em conflito aberto com as categorias sociais que tem por baixo, enquanto mansamente se subordina ou concilia com aquelas que se emparelham na sua própria altura ou estão acima dela.

Para esses grupos acatar reivindicações da classe trabalhadora que se manifestava no intenso movimento grevista que assolava os centros urbanos, assim como as propostas de reforma agrária advinda das Ligas Camponesas (o que se impunha como necessidade pelo estágio de desenvolvimento que o capitalismo alcançava já naquele momento) se configurava como uma ameaça à propriedade privada e a acumulação capitalista, conforme aponta Francisco de Oliveira referindo-se ao problema agrário:

A solução do chamado "problema agrário" nos anos da "passagem" da economia de base agrário-exportadora para urbano-industrial é um ponto fundamental para a reprodução da expansão capitalista. Ela é um complexo de soluções, cujas vertentes se apóiam no enorme contingente de mão-de-obra, na oferta elástica de terras e na viabilização do encontro desses dois fatores pela ação do Estado construindo a infra-estrutura, principalmente a rede rodoviária. Ela é um complexo de soluções cujo denominador comum reside na permanente expansão horizontal da ocupação com baixíssimos coeficientes de capitalização e até sem nenhuma capitalização prévia: numa palavra, opera como uma sorte de "acumulação primitiva. (OLIVEIRA, 2003, p.42). 
Tal acumulação primitiva se coloca na realidade como a ponta de um iceberg cujas bases estão na permanente atrofia do capital no país, conforme aponta Chasin. Assim, nesta articulação entre o arcaico posto nas relações agrárias e o novo expresso pelos interesses decorrentes do patamar de desenvolvimento a que o capitalismo chegara naqueles idos anos da década de 50, a abertura política trazia à tona a expressão dos explorados, cuja condição chegava aos limites das possibilidades de sobrevivência.

O impasse, portanto na correlação de forças políticas era justamente o de superar as divergências entre os segmentos das burguesias urbanas e rurais e definir qual seria a velocidade da implantação das medidas repressivas para expurgar esses entraves ameaçadores ao desenvolvimento capitalista nacional no rastro do capital internacional.

\section{A crise do Modelo Desenvolvimentista}

Conquanto a historiografia acentue a divisão no governo de JK entre nacionalistas e internacionalistas ${ }^{3}$, o partido comunista, segundo o relatório do sensor infiltrado do DOPS-SP naquele partido, parece ter expressado com mais clareza qual era verdadeiramente a separação que se punha naquele ano de 1956.

Em reunião composta por integrantes do Comitê Central do Partido Comunista do Brasil considerava que o governo de JK, conforme o posicionamento ideológico estava cercado por três alas: democrata, reacionária e golpista. A primeira, integrada pelo general Teixeira Lott, J osé Maria Alkmin, ministro da fazenda e, ainda, pelo chefe da Casa Civil da presidência da república; a segunda, pelos "entreguistas" Macedo Soares, Nereu Ramos e Assis Chateaubriand; a terceira, por Pena Botto, Amorim do Vale e outros, que tudo estariam fazendo - apoiada pela segunda, no sentido de aumentar ainda mais a discórdia entre as Forças Armadas e o desprestígio do presidente da república. Segundo este mesmo relato, para o PCB a ala chefiada pelo general Lott, com o apoio dos verdadeiros democratas e patriotas, não permitiria que os "reacionários" e "golpistas" prosseguissem nas suas contendas, entreguismos e calúnias.

\footnotetext{
${ }^{3}$ Divisão esta considerada no governo J K entre os intelectuais da ESG denominados de "sorbonistas" cujo posicionamento político os aproximava do projeto liberal ou internacionalista e de outro os nacionalistas que era a facção do exército simpatizante com as idéias getulistas, consideravam necessário garantir o desenvolvimento da nação um pouco mais distante do poderio do capital internacional.
} 
Diante disso, o Partido Comunista do Brasil decidiu:

1) Apoiar, de maneira decisiva e direta, todos os atos da "ala democrata"; 2) Cessar, até nova deliberação, todos os ataques e críticas à pessoa do Sr. Presidente da República; 3) Apoiar os bons atos do Sr. Presidente da República e criticar de maneira democrática e construtiva os atos considerados prejudiciais ao povo; 4) Prestigiar, sempre que possível, o Sr. Presidente da República e repudiar os "reacionários" e "golpistas" que compõem o seu governo e, 5) Todos os movimentos de massa de agora em diante deverão ser de âmbito nacional e em conjunto com todos os setores de trabalho. Em todos os movimentos deve ser colocado em primeiro plano o caso Fernando de Noronha 4 , o qual vem surtindo os efeitos desejados e empolgando o povo em geral. [...] Caso as pretensões dos comunistas falharem, o sr. Presidente da República sofrerá campanha de desmoralização jamais vista no país. 5

Diante daquelas possibilidades de "abertura democrática" era compreensível que o PCB e outras agremiações democráticas, como sindicatos e os integrantes dos movimentos que se colocavam como nacionalistas (Movimento em Defesa do monopólio do Petróleo, Movimento contra o acordo Brasil- Estados Unidos, Movimento contra a proliferação da bomba atômica etc.) apostassem nesses novos tempos de grandes transformações na sociedade brasileira, pois diante de um passado muito recente (a experiência da ditadura estadonovista), aquelas propostas de desenvolvimento econômico e político e o grande debate que se seguia na sociedade civil vislumbravam mudanças efetivas nas relações entre o capital e o trabalho.

Mas a lógica da implantação econômica imposta pelo plano de metas do governo J K, vislumbrando o pseudo "pacto social" em garantir a participação de todos os segmentos sociais nas benesses da industrialização nacional, revelava a sua falácia já no primeiro ano do seu governo (1957), pois as divergências com os segmentos da burguesia dominante deixavam claro que aquele "pacto" era o limiar entre os interesses da estabilização monetária defendida pelos organismos internacionais (FMI) e segmentos do grande capital, e a aceleração do projeto desenvolvimentista fincado na emissão monetária e na política de facilitação do crédito, beneficiando o médio capital.

A busca pelo incremento industrial ficava nítida nos mecanismos econômicos do governo, em detrimento das contenções inflacionárias que influíam diretamente no bolso dos trabalhadores, conforme aponta Sarmento (2009),

\footnotetext{
4 A negociata que o PCB se refere e que no final do ano de 1956, J uscelino toma uma decisão que provocou bastante controvérsia em todo o país: em troca de um empréstimo de Cem Milhões de Dólares em armamento, o Brasil cedeu a ilha de Fernando de Noronha para que os norteamericanos ali instalassem uma base de rastreamento de foguetes.

${ }^{5}$ Informação reservada: Resolução aprovada pelo Comitê Central do Partido Comunista do Brasil. Relatório Reservado Dossiê DOPS. 50.Z.09. documento número 372-A e B de 05/ 12/ 1956.
} 
o compromisso com a execução do plano também pode ser observado na forma pela qual Alkmin procurou definir uma política monetária destinada a conter o processo inflacionário. O ministro buscou limitar o processo de expansão da moeda através da restrição do crédito ao setor privado, mas, de maneira conflitante, empenhou-se em adotar medidas que viabilizassem maior disponibilidade de recursos para os investimentos do setor público e para o subsídio de atividades industriais consideradas de interesse estratégico. Assim, uma vez mais, tornavam-se explícitas as prioridades do governo Kubitschek.

Diante das limitações intrínsecas desse desenvolvimentismo, os descontentamentos pululam em vários âmbitos da sociedade. Não só os trabalhadores se mobilizaram - no período entre 1956 a 1961 foram deflagradas 168 greves somente na capital federal, mas também os cafeicultores - que, em maio de 1957, chegaram a organizar uma marcha contra o "confisco cambial". Conforme Marcelo Mattos (2004, p. 243),

[...] é justamente no período da segunda metade dos anos 50 e primeiros anos da década de 1960 que a curva de movimentos grevistas toma um rumo ascendente significativo, com saltos sucessivos no número de paralisações, que configuraram uma das fases mais dinâmicas do movimento operário brasileiro.

Ante o descontentamento generalizado tanto dos trabalhadores quanto das classes médias e dos setores da própria burguesia ante a iminente crise, novamente emerge os boatos de que um golpe se avizinha. Um terreno fértil para as elucubrações reacionárias da burguesia autocrática, para a qual as movimentações operárias e da sociedade civil eram considerados como falência da "ordem democrática", alinhando as camadas mais retrógradas nas propostas de fechamento do regime.

Mais uma vez o porta voz destes augúrios boatos é a ave de agouro: “o corvo" Carlos Lacerda ${ }^{6}$ como o denominavam seus adversários. Este juntamente com o presidente do MMC, Coronel J osé Alberto Bittencourt, anunciava na Rádio Nacional que estavam: "marchando pavorosamente para um terceiro golpe militar". ${ }^{7}$

Apesar do apoio inicial do MMC ao governo Juscelino, diante do quadro de insatisfação dos setores trabalhistas e da classe média e ante as várias denúncias de corrupção governamental, os integrantes do MMC passam a fazer coro às críticas de seus pares de "direita” que eram contrários ao governo J K. Aponta para a falência do poder civil em governar o país cujas distensões formavam um quadro conjuntural propício para golpes.

\footnotetext{
${ }_{6}^{6}$ Segundo Wagner William o presidente J uscelino Kubitscheck proibiu que Carlos Lacerda falasse no rádio e na televisão, através de uma nova cláusula contratual que impedia a transmissão de manifestações contra o governo. Era a "cláusula R", que só seria suspensa no final de 1958.

${ }^{7}$ Recorte do jornal "Tribuna da imprensa" de 18/03/ 1958. Anexo ao Relatório Reservado do DOPS 50.Z.09. Documento no 413.
} 
Durante vários dias seguidos o jornal "Tribuna da Imprensa” de propriedade de Carlos Lacerda, divulga as declarações do coronel com o claro intuito de desestabilizar o apoio do exército ao governo de J K. Como o MMC era um movimento civil-militar e o general Lott o seu mentor, criava-se uma situação delicada tanto para o governo como para o ministro da guerra. Tanto os setores mais radicais das Forças Armadas como a UDN, aguardavam do general Lott alguma punição ao coronel (apesar de fomentarem a polêmica), pois sendo ele simpatizante de tal movimento, deixavam o ministro entre a "cruz e a espada". As manchetes como sempre sensacionalistas: "Coronel J osé Alberto Bittrencourt pertence a um grupo de oficias golpistas que tentam mostrar a falência do poder civil no Brasil". ${ }^{8}$

O general Lott, embora recebesse de seus adversários a pecha de "inocente útil ou massa de manobra" assume a frente do debate na imprensa, dada a rede de informações que possuía muito mais ampla do que se pudesse imaginar. Muito bem informado sobre os bastidores da política e da polícia política, tinha à sua disposição o Serviço Secreto do ministério do exército que o munia de informações. Conforme analisa o pesquisador Wagner Willian cujo trabalho versa sobre este general, dada a incerteza que se punha desde o início do governo de J uscelino, esse gradativamente fora assumindo o comando desse serviço, sempre assessorado diretamente pelo major Alencar, que tinha a experiência do Serviço de Informações em São Paulo, “Lott incrementou o dispositivo que informava o ministro, vital naquele momento em que, por qualquer motivo, se falava na queda de J uscelino". (WILLIAM. 2005, p. 226).

Pois esta rede de informações também possuía pessoas infiltradas que produziam documentos sobre o próprio Lott que eram enviados não a ele, é evidente, mas ao chefe do Serviço Secreto, conforme podemos observar pelo documento reservado emitido em 14/ 04/ 1958, com notícias sobre o MMC e sobre o general Lott:

Fonte militar muito bem informada, nos informa que cresce, dia a dia, o descontentamento da facção novembrista do MMC em relação à pessoa do ministro da guerra. Essa indisposição desses comunistas funda-se nos reiterados pedidos do ministro, ao presidente, para que seja punido o Cel. Alberto Bittencourt, além de pleitear medidas visando combater o comunismo e de mandar abrir inquéritos para apurar deslizes nas administrações militares. ${ }^{9}$

O general Lott, como tentáculo do "nacionalismo desenvolvimentista" e do "legalismo democrático", mesmo com sua rede de apoio político passa então a ser visto

\footnotetext{
8 Os documentos: Relatório Reservado do DOPS. 50.Z.09. Documentos nํㅗ 415 de 21/ 03/ 1958; 416 a 421 de 22 a 26/ 03/ 1958.

9 Secreto Fls. 70. 14/04/1958, do Rio de Janeiro. Relatório Reservado Dossiê DOPS. 50.Z.09. Documento no 435 .
} 
como uma autoridade de esquerda que poderia colocar em risco a autoridade do Estado, favorecendo o avanço comunista.

Apesar do equivoco do julgamento de seus pares em considerá-lo de esquerda e simpatizante do Partido Comunista, o general Lott era a garantia da continuidade do governo no equilíbrio delicado entre os setores da ESG e os militares getulistas e sua fragilização representava no seio dos militares o fortalecimento do grupo sorbonista que se via em uma rede de oposição que se ampliava gradativamente - IBAD ${ }^{10}$, IPES ${ }^{11}$, $\mathrm{ADESG}^{12}$, FIESP ${ }^{13}$, imprensa, igreja católica, com o objetivo claro de inserção deste grupo no controle do Estado num futuro não muito distante.

É neste sentido que os pronunciamentos de integrantes do MMC atingem diretamente a tropa que, conforme observa o censor, afronta as ordens do Ministro da Guerra. O general Arquiminio Pereira, comandante da Infantaria do $2^{\mathrm{o}}$ Exército sediado em São Paulo, ter-se-ia recusado a aceitar, sob o seu comando, o coronel Tácito Lívio Reis de Freitas, por considerá-lo comunista. Esta informação circulou com insistência nos meios militares, tendo grande repercussão, pois estava assentada a indicação do coronel pelo ministro da guerra para o comando do regimento de Infantaria sediado em Lorena-SP. Mas o referido nem chegou a tomar posse. ${ }^{14}$

Apesar dos discursos anticomunistas do general Lott e conseqüentemente do MMC, os seus adversários queriam o expurgo da entidade do seio das Forças Armadas, justificada por acusações de indisciplina, rompimento da hierarquia militar e afrontamento ao próprio Estado constituído.

No interior destas divergências ressurge o Clube Militar como o espaço onde as contendas das Forças Armadas atingem o clímax e em cuja eleição se verifica para que lado pende o pêndulo desta correlação de forças,

estamos seguramente informados de que ainda não há nenhum rompimento entre os elementos do grupo do MMC com o general Lott; é fato que os primeiros estão descontentes com o ministro, ainda mais que este insiste em punir o coronel Alberto Bittencourt. Essa situação de expectativa nas relações MMC-Lott prosseguirão até o final da eleição do Clube Militar. Do seu resultado dependerá o pronunciamento em definitivo daquela ala do Partido Comunista no Brasil sob o rótulo de Movimento Militar Constitucionalista. ${ }^{15}$

${ }^{10}$ Instituto Brasileiro de Ação Democrática, fundado em 1959

${ }^{11}$ O Instituto de Pesquisas e Estudos Sociais, fundado em 1962

${ }^{12}$ Associação dos Diplomados da Escola Superior de Guerra, fundada em 1951

${ }^{13}$ Federação das Indústrias do Estado de São Paulo, fundada em 1931

14 Recorte do jornal "Diário da Noite" de 15/04/1958. Anexo ao Relatório Reservado do DOPS. 50.Z.09. Documento no 430.

${ }^{15}$ Informação Reservada fls. № 63. São Paulo, 16/ 04/ 1958. Anexo ao Relatório Reservado do DOPS. 50.Z.09. Documento no 434. 
Neste ínterim a imprensa começa a especular sobre a possibilidade da reeleição de Juscelino, noticiando a existência de uma "Lei da Fidelidade", denunciada com alarde pela oposição e pela imprensa antigovernistas como um plano para que este se mantivesse no poder após seu período de quatro anos, o que, segundo documento do serviço de vigilância, o MMC não apoiaria.

Assim relata o censor infiltrado na reunião do Deputado Roxo Loureira16 em 18/ 04/ 1958, onde se reuniram além do deputado os coronéis: Nemo Canabaro, Sólon Estillac Leal, Alberto e Alexino Bittencourt, Henrique Oest, Sá Benevides e Ari de Abreu Barreto, além de outros. Nessa reunião foi debatido o caso da mensagem da Lei de Fidelidade $^{17}$, aliás, com total reprovação dos supracitados militares. ${ }^{18}$

No dia seguinte a reunião ocorreu na residência do Coronel Alexino Bittencourt, tendo novamente como pauta a Lei de Fidelidade e a demissão do coronel Alberto Bittencourt. O MMC que havia sido criado no bojo da crise sobre a legalidade do mandato de J uscelino Kubitschek, agora se sentia a margem do apoio presidencial e de sua plataforma política e via na continuidade do mandado de $\mathrm{J} K$, tanto uma ameaça à ordem constitucional como a possibilidade do país marchar para uma ditadura de direita. ${ }^{19}$

Nesta expectativa de desestabilização, os censores do Serviço Secreto acompanham também a movimentação operária. Naquela conjuntura de penúria da classe trabalhadora, o fortalecimento dos trabalhadores os leva á unificação em torno de um ponto único que atingia a todos diretamente: a obrigatoriedade da assiduidade integral. Tal problema e as tentativas de fundar uma organização que os aglutinasse já advinham dos anos iniciais da década de 50. Mas será em 1958 que conseguem fortalecer a comissão no interior do Pacto de Unidade Intersindical (PUI) ${ }^{20}$. Assim em 04/ 09/ 1958 lançam um manifesto criticando a presença de trustes internacionais no país. Segundo este manifesto o PUI cumpria o dever de alertar os trabalhadores e o povo para a gravidade da situação decorrente das manobras que vinham sendo feitas pelos trustes internacionais com a cumplicidade de elementos instalados nos altos postos do governo federal e que visavam promover o total estrangulamento da nossa

${ }^{16}$ Não foram encontrados dados sobre o referido deputado.

17 "Lei da Fidelidade", denunciada com alarde pela oposição e pela imprensa antigovernistas como mero plano para que J uscelino se mantivesse no poder após seu período de quatro anos e assim por diante.

18 Informe Secreto fls. 95. Reúnem-se elementos do MMC.- Discutiram vários assuntos, inclusive Lei de Fidelidade e a demissão do Cel. Bittencourt. Relatório Reservado Dossiê DOPS. 50.Z.09 Documento no 446 de 19/ 04/ 1958

19 Informe Secreto fls. 75. Reunião de Militares da Ala Nacionalista na residência do Deputado Roxo Loureiro. Relatório Reservado Dossiê DOPS. 50.Z.09 Documento no 445 de 18/ 04/ 1958

20 Pacto de Unidade Intersindical (PUI) foi criado em junho de 1953, com a participação de mais de 100 organizações sindicais. Em 1958, o PUI foi substituído pelo Conselho Sindical dos Trabalhadores (CST), agrupando o PUI de São Paulo, ABC, Sorocaba e o Fórum Sindical de Debates de Santos. 
economia como meio de quebrar o Estatuto do Petróleo e de liquidar a Petrobrás, empreendimento básico para a conquista de nossa emancipação econômica. ${ }^{21}$

O manifesto advertia também que o próprio governo dos Estados Unidos da América do Norte, cuja política representava os interesses dos grupos econômicos internacionais, alarmados e inteiramente contrários ao surto de desenvolvimento industrial do país, vinha tomando medidas discriminatórias de caráter político e econômico contra o Brasil. E citava como exemplo, a da recente visita do Sr. Foster Dulles ao Brasil com o objetivo de conseguir do governo a alteração da política nacionalista do petróleo, a exemplo de que ocorrera com o governo Frondizi na Argentina $^{22}$.

Em relação à cafeicultura, dizia ainda o manifesto, que os trustes internacionais passaram a promover o estrangulamento de nossa economia atacando fulminantemente o café, afastando-o dos principais mercados mundiais, o que tudo isso fora possível dado o controle absoluto da Bolsa de Nova Iorque sobre o preço do café. Assim, o desequilíbrio da nossa balança de pagamentos, decorria da redução das entradas de divisas obtidas com a exportação desse produto que paralisara os negócios no mercado interno. Os cafeicultores não podendo também vender o produto, não estavam em condições de pagar aos trabalhadores rurais, cujos contratos ainda não haviam sido renovados e não tinham possibilidade de sê-lo, a manter-se aquele estado de coisas. Diante disso, "a indústria e o comércio iriam sentir as conseqüências de uma quase completa paralisação das compras. As conseqüências finais seria o desemprego em massa, provocando a agitação social e o desespero de 60 milhões de brasileiros. ${ }^{23}$

O manifesto não para por aí, denunciando em seguida como entreguistas da nação brasileira: Assis Chateaubriand, o ministro da Fazenda Lucas Lopes, J osé Maria Whitaker ${ }^{24}$ (segundo o manifesto, um preposto dos trustes internacionais), Renato Costa Lima. ${ }^{25}$ Todos afinados com a entrada do capital multinacional, principalmente norte-americano.

${ }^{21}$ Recorte do jornal "Noticias de Hoje" de 05/09/1958. Anexo ao Relatório Reservado do DOPS. 50.Z.09. Documento no 468.

22 Em 1958 Arturo Frondizi, pela União Cívica Radical Intransigente e com um projeto desenvolvimentista, ganhou as eleições presidenciais com apoio do peronismo ilegalizado. Seu governo foi economicamente alinhado com os Estados Unidos - fazendo parte da Aliança para o Progresso - e diplomaticamente independente, com apoio a Cuba após a imposição do embargo econômico estadunidense.

23 Recorte do jornal "Noticias de Hoje” de 05/ 09/ 1958.Anexo ao Relatório Reservado Dossiê DOPS 50.Z.09. Documento nํ468.

${ }^{24}$ J osé Maria Whitaker político influente desde a década de 30 retornou ao Ministério da Fazenda por um curto período, entre abril e novembro de 1955, durante o governo do presidente Café Filho.

25 Diretor da Carteira de Crédito Agrícola do Banco do Estado de São Paulo e secretário de Agricultura durante o governo de Lucas Garcez (1951-1955), em 1957 assumiu a presidência da 
Apesar do manifesto identificar os verdadeiros problemas que assolam o país, denunciando que a política econômica voltada para o capital multinacional era o responsável pelas péssimas condições do povo brasileiro, os sindicalistas "pedem socorro" aos mantenedores daquela ordem, isto é, os militares,

Invocamos as nossas Forças Armadas e o nosso glorioso Exército e conclamamos seus mais destacados chefes - baluartes na defesa dos superiores e sagrados interesses do Brasil - para que se unam e atendam os apelos dos trabalhadores e do povo no sentido de preservar as nossas riquezas e garantir os direitos e as liberdades constitucionais também ameaçadas pelos entreguistas, pois que estes não terão escrúpulos em recorrer ao golpe contra as instituições para atingir os seus escusos objetivos. ${ }^{26}$

A conclamação das centrais sindicais, onde o apoio do vice-presidente J oão Goulart se fazia presente, no exército, só fez aumentar uma "fossa abissal” entre as demandas dos operários e seu reconhecimento por parte da autocracia burguesa e das Forças Armadas, dada a leitura simplista que faziam, ou seja, que tais mobilizações expressavam o "inimigo interno" a ser aniquilado. Além disso, essa busca de participação no debate nacional por parte da classe trabalhadora, segundo os militares "era um despropósito", pois os destinos e a responsabilidade de administrá-los seriam exclusivamente da elite burguesa, representada pela Forças Armadas. ${ }^{27}$

Nesse sentido com uma linguagem rebuscada de chavões nacionalistas, que é o discurso que impera em todos os segmentos sociais naquela conjuntura, os sindicalistas reivindicam o progresso nacional articulado com o capital nacional. Entendiam os sindicados que a luta de classes não poderia ser resolvida por ser produto da acumulação de capital e da má distribuição de renda nas mãos da burguesia dominante, mas, fundados na convicção da racionalidade capitalista de desenvolvimento endógeno, consideraram que, fora dos tentáculos do capital internacional, a conquista dos direitos das classes subalternas seria conquistado em médio prazo melhorando as suas condições de existência, o que colocava como perspectiva uma aliança entre os trabalhadores e o Estado constituído.

Os integrantes do PUI conclamam também o general Teixeira Lott, a quem atribuem a "esperança nacionalista e a possibilidade da legalidade democrática", a

Sociedade Rural Brasileira. Em setembro do ano seguinte, tornou-se presidente do Instituto Brasileiro do Café (IBC).

${ }^{26}$ Recorte do jornal "Noticias de Hoje” de 05/ 09/ 1958. Anexo ao Relatório Reservado Dossiê DOPS 50.Z.09. Documento no 468.

${ }^{27}$ No interior da ESG os "sorbonistas" acreditavam que as razões do nosso subdesenvolvimento eram intrínsecas às características do povo brasileiro, cujas massas eram despreparadas, subdesenvolvidas, analfabetas e sem condições de manifestação próprias em defesa de seus interesses. Em conformidade com o que pregavam os segmentos dominantes da burguesia, consideravam que caberia à elite nacional imbuí-las de valores nacionais e projetar o caminho a ser seguido pela nação. 
“gloria e esperança de nosso povo, para que, mais uma vez não permita seja traída a nossa pátria, para que continue em pleno vigor o império da lei e da ordem. “28

O PUI buscava a adesão do poder executivo, legislativo, sindicatos, associações de bairro, grêmios estudantis, sempre em nome da preservação das divisas nacionais e da garantia de melhores condições de vida do povo brasileiro. Após a convocação geral da nação em defesa desses princípios, o manifesto exige das autoridades: $1^{\mathfrak{o}}$ Exigir do presidente da república que nomeasse para a junta administrativa do Instituto Brasileiro do Café (IBC) ${ }^{29}$, um representante do exército nacional escolhido pelo ministro da guerra, um representante dos trabalhadores escolhido em assembléia Intersindical convocada pelo PUI, e um representante do parlamento nacional, a ser escolhido em reunião conjunta do Senado e da Câmara, sem a presença dos quais, não poderia ser tomada qualquer decisão que alterasse a atual política do governo sobre o café; $2^{\text {o }}$ Manifestar ao presidente da república a preocupação dos trabalhadores quanto a qualquer mudança na política cambial, cuja permanência entendiam ser necessária e imprescindível para o atendimento ao surto de desenvolvimento industrial que se verificava.

Faz-se mister salientar que o PUI, apesar da heterogeneidade dos seus componentes, era eminentemente urbano e operário, e as principais reivindicações do documento giram em torno de uma política de proteção à agricultura agro exportadora, no caso "defender" o nosso melhor produto, o café, e uma política cambial que favorecesse e incentivasse a entrada de capitais para o incremento industrial que já se fazia presente; pois seus integrantes também estavam em sintonia com a "onda desenvolvimentista", apostando na industrialização como conquista da cidadania na perspectiva do pertencimento às nações desenvolvidas ocidentais.

Como terceiro ponto o manifesto apelava para o presidente da Câmara Federal para que convocasse e exigisse o comparecimento de todos os representantes do povo naquela Casa, garantindo "quorum" para que fossem realizadas normalmente as sessões, imprescindíveis para assegurar o normal funcionamento das instituições e a defesa de nossa Carta Magna; e retomava o apelo ao apoio de Lott por considerá-lo o

${ }^{28}$ Recorte do jornal "Noticias de Hoje” de 05/ 09/ 1958.Anexo ao Relatório Reservado Dossiê DOPS 50.Z.09. Documento no 468.

${ }^{29}$ Devido à importância do café nas exportações brasileiras, foi criado, em 1931, o Conselho Nacional do Café (CNC), que, em 1933, foi substituído pelo Departamento Nacional de Café (DNC), autarquia federal subordinada ao Ministério da Fazenda, que controlou o setor até 1946. Em 1952, foi criado o Instituto Brasileiro do Café (IBC), formado principalmente por cafeicultores, que definiu as diretrizes da política cafeeira até 1989. 
defensor das liberdades constitucionais e democráticas e da emancipação econômica nacional. ${ }^{30}$

No caso, observa-se como a bandeira da industrialização e do desenvolvimento social, passa a ser assumida também pelos sindicados que apostam ainda no velho "pacto social" do período de Getulio e que agora, na fala do seu "herdeiro político", se manifestava na valorização da experiência da classe trabalhadora a qual conclamava para construir uma "nova nação" cujos empreendimentos econômicos garantiriam uma distribuiçãojusta da renda produzida por eles mesmos.

Nesta perspectiva reivindicatória sindical de mudanças políticas, o Plano de Metas sofria pressão de todos os lados, a começar pelo capital estrangeiro que só continuaria a entrar no país sob a condição de que se desenvolvesse uma política de austeridade fiscal, o que inviabilizaria a conclusão do Programa. Internamente, o governo enfrentava as pressões e críticas dos interesses estrangeiros e dos sindicatos trabalhistas, os redobrados ataques da UDN e dos grupos exportadores (cafeicultores). A ordem só era possível por meio de ameaças ou pela própria repressão aos movimentos populares.

O que se colocava era, conforme já indicamos a emergência das reformas mais radicais que subordinassem o campo à cidade - de que uma reforma agrária seria um exemplo -, posto pelo próprio desenvolvimento da industrialização, o que denota, mais uma vez, o conservadorismo arcaico a permear as relações de dominação da burguesia no país. Neste sentido a "perfeita harmonia" aludida por Francisco de Oliveira, entre a concentração da propriedade fundiária e o desenvolvimento industrial revelava que a contradição estava posta e cada vez mais se acentuava, a considerar os dados apresentados por Dreifuss,

o processo de concentração industrial foi acompanhado por uma extrema concentração de posse da terra. De 1950 a 1960 o número de grandes propriedades baixou de 2,3\% do total de estabelecimentos agrícolas para $0,98 \%$. Assim mesmo, esses últimos controlavam até $47,29 \%$ da terra, ao passo que $10,4 \%$ dos estabelecimentos agrícolas controlavam $79,9 \%$ da terra. O comércio agrícola estava ligado a uma grande parte da estrutura bancária. (DREIFUSS, 2006, p. 69).

Neste sentido o aumento da mobilização dos trabalhadores rurais cujas propostas de reforma advinham da necessidade de regularização da condição fundiária dos pequenos produtores rurais subsumidos à grande propriedade, representava uma ameaça efetiva capaz de alteração do "status quo". A evidência do pânico da burguesia se observa nos pronunciamentos das Forças Armadas e da grande imprensa que

30 Recorte do jornal "Noticias de Hoje” de 05/ 09/ 1958.Anexo ao Relatório Reservado Dossiê DOPS 50.Z.09. Documento no 468 . 
enfatizam, mais uma vez, o perigo desses movimentos populares serem ministrados pela infiltração comunista, colocando em risco todos os "avanços democráticos" que a nação usufruía.

O relatório a seguir, do Serviço Secreto, demonstra coincidentemente que no mesmo momento em que a PUI convocava todas as agremiações da sociedade civil para lutar por melhores condições de vida e defender o patrimônio nacional, lançava-se na imprensa burguesa, representada pelo seu maior baluarte, o jornal "A Tribuna da Imprensa" em 24/ 10/ 1958 uma notícia cuja função só poderia ser a de formar opinião pública contra qualquer articulação social que não fosse endossada pelo Estado e pelas Forças Armadas. Tratavam-se, mais uma vez, da acusação sem fundamento nenhum, de que comunistas haviam explodido um depósito de armas das forças do exército.

Assim começava a manchete:

Comunistas acusados da explosão de Deodoro! “ A Polícia do Exército e investigadores da Divisão de Polícia Política e Social prenderam, ontem diversos comunistas, transportando-os, incomunicáveis, para a 1a Divisão de Infantaria, como responsáveis pela explosão dos paióis do Depósito de Munições de Deodoro. ${ }^{31}$

Segundo a notícia, o ato subversivo era para provocar o adiamento das eleições que estariam acontecendo naqueles dias para deputados, senadores e governadores. $\mathrm{O}$ interessante que essa seria a segunda explosão provocada nos paióis de Deodoro. Na primeira ocorrida em agosto de 1958, as autoridades chegaram à conclusão que fora acidental. Conforme a acusação, devido à grande movimentação que houvera em relação ao acontecido naquela ocasião, o PCB teria resolvido explodi-lo novamente para criar tumulto e adiar o pleito eleitoral.

Os civis participantes que estavam envolvidos no tal atentado tinham cargo diretivo em associações de classe trabalhadora e de bairros e seriam como o artigo deixa entrever, considerados pelo partido como elementos descartáveis, usados como "massa de manobra". Desta forma, mais uma vez, a proposta era a de desacreditar aquela organização até mesmo entre seus adeptos, dada a falta de humanidade que estariam revelando.

Antonio Albuquerque, um dos presos, é presidente da Associação dos Vendedores Ambulantes do Rio de J aneiro e está registrado na DPPS como "elemento ativista-militante do Partido Comunista. Os arquivos daquela Divisão especializada registram, ainda, a existência de numerosos núcleos comunistas em Deodoro, que funcionam como "organizações de base". Estas, geralmente, são constituídas de três a cinco pessoas subordinadas aos "comitês de bairros". Leitão, outro dos

${ }^{31}$ Recorte do jornal "Tribuna da Imprensa" de 24/ 10/ 1958. Anexo ao Relatório Reservado do DOPS 50.Z.09. Documento no 501. 
presos, é presidente da Associação Pró-Melhoramentos de Guadalupe, que os agentes da DPPS acreditam funcionar como "comitê de bairro", enquanto o tenente Guimarães é também elemento ligado aos outros dois. Esses três seriam elementos utilizados pelo PC para determinadas missões e teriam executado, com alguns auxiliares, o plano de fazer explodirem os paióis. ${ }^{32}$

Haveria ainda um quarto elemento não identificado pelas autoridades, "esse corpo foi encontrado no interior do paiol, em local de acesso proibido a estranhos, inteiramente calcinado." O coronel Danilo Cunha da Divisão de Polícia Política e Social (DPS) tardava em concluir as investigações e suas discordâncias denotam o ardil que se entrevê na boataria sobre o episodio. Por não concordar com o laudo do IML enviado ao General Dantas Ribeiro responsável pelo inquérito militar o coronel faz a seguinte declaração ao repórter que o entrevistava,

O Cel. Danilo confirmou a prisão dos comunistas e esclareceu-nos que a detenção dos suspeitos foi iniciativa exclusiva das autoridades da 1 a Divisão de Infantaria. Acrescentou que a equipe da DPPS apenas colaborou nas diligências. Nada adiantou sobre os depoimentos dos presos e disse ser prematura a afirmativa de que a explosão teria sido causada por sabotagem. Os meios militares mostram-se reservados sobre o assunto, pois o IPM é de caráter sigiloso. ${ }^{33}$

A criminalização prévia sem comprovação do resultado das perícias policiais se manifesta também nas notícias publicadas pela "Tribuna da Imprensa" que se adianta no julgamento, assim como os membros das Forças Armadas. Mais notável é constatar que nem mesmo um membro da temida DPS (onde se encontra o Serviço de Informações) se arriscava em acusar os suspeitos (disse ser prematura a afirmativa de que a explosão teria sido causada por sabotagem) sem as devidas diligências da investigação.

Como se vê novamente a movimentação golpista entra em ação, criando "fatos novos" que pudessem de alguma maneira criar uma polêmica que insuflasse as Forças Armadas e a opinião pública. A tática dos golpistas era demonstrar que o PCB estava sempre provocando "atentados" à segurança pública e que seus simpatizantes estavam infiltrados principalmente nas organizações da classe trabalhadora. Na seqüência associavam o estardalhaço à figura do general Lott acusado de facilitador daquela situação, por se tratar, segundo eles, de "um simpatizante dos comunistas".

Tal agitação não se resumia às Forças Armadas, conforme já o demonstramos e as articulações da UDN são assim veiculadas pela imprensa do Partido Comunista,

\footnotetext{
32 Recorte do jornal "Tribuna da Imprensa” de 24/ 10/ 1958. Anexo ao Relatório Reservado do DOPS 50.Z.09. Documento ํo 501.

33 Idem.
} 
Plano sinistro e liberticida está sendo meticulosamente elaborado na cúpula da UDN - O estopim da sublevação seria uma entrevista do brigadeiro Eduardo Gomes ${ }^{34}$ e sua conseqüente prisão - Três meses seriam suficientes à preparação do complô - Desgastar Lott politicamente e atacar os pontos fracos do governo $\mathrm{J} \mathrm{K}$, para criarem o clima propício à agitação, à desordem e à violência - Nova J acareacanga. ${ }^{35}$

Para o referido jornal ${ }^{36}$ essa conspiração contra a legalidade constitucional teria como mentores o brigadeiro Eduardo Gomes, o empresário e deputado Herbert Levy37, o presidente da UDN J uraci Magalhães ${ }^{38}$ e o jornalista J ulio de Mesquita Filho ${ }^{39}$. Via o jornal um novo plano liberticida, tendo como objetivo imediato o afastamento do general Henrique Teixeira Lott do ministério da guerra. Os articuladores da nova trama, que em sua imensa maioria se identificavam com a cúpula reacionária da UDN, participariam e estariam dirigindo os entendimentos que levariam o país a um clima de agitação, desordem e violência, até hoje não experimentados.

A eclosão desses acontecimentos, de conseqüências imprevisíveis, dar-se-ia após um "sinal", que consistiria da prisão do brigadeiro Eduardo Gomes após uma entrevista provocativa e insultuosa ao Exército na pessoa de seu ministro,

estamos seguramente informados que o complô em gestação é uma manobra golpista de envergadura, diferente das escaramuças que o país tem testemunhado a partir de 11 de novembro de 1955. O que se propõem agora os golpistas é uma campanha de maior profundidade, obedecendo a planos que estão sendo meticulosamente elaborados e tendo em vista uma tática de diferentes aspectos, ligados entre si. Trata-se de um verdadeiro complô, cujo alvo principal é o general Lott. Pretendem os inimigos da democracia desfechar uma campanha sem precedentes pela sua violência, com o propósito de alcançar, desta feita, o que não conseguiram até agora: afastar do ministério da guerra o general Lott.40

O jornal anunciava ainda que, embora o brigadeiro Eduardo Gomes negasse o envio de carta ao presidente da república no sentido de pressioná-lo a promover

${ }^{34}$ O udenista Eduardo Gomes já concorrera à duas eleições presidenciais (em 1945 e 1950, perdendo respectivamente para Dutra e Vargas. Asssumindo o ministério da Aeronáutica no governo de Café Filho (1954-1955), será um dos protagonistas do golpe de 1964.

35 Recorte do jornal "Notícias de Hoje" de 23/12/1958. Anexo ao Relatório Reservado do DOPS 50.Z.09. Documento no 530.

36 "Notícias de Hoje" era o órgão oficial do PCB, era um jornal diário, vendido em bancas e também por militantes comunistas em sindicatos, portas de fábricas e centros operários.

37 Dez vezes deputado federal e proprietário do jornal econômico-financeiro 'Gazeta Mercantil', Herbert Victor Levy, participou da fundação da UDN (União Democrática Nacional).

38 O udenista ex governador da Bahia, Juraci Magalhães, fora nomeado em 1950, presidente da Companhia Vale do Rio Doce e, em seguida, adido militar brasileiro nos Estados Unidos, assumindo em 1954 a recém-fundada Petrobrás. Em 1957 passou a presidir a UDN e em 1964 participou da conspiração que derrubou o presidente J oão Goulart.

39 J ornalista e advogado paulista, proprietário do jornal "O Estado de São Paulo" de posição conservadora.

40 Recorte do jornal "Notícias de Hoje" de 23/12/ 1958. Anexo ao Relatório Reservado do DOPS 50.Z.09. Documento no 530 . 
reformas nas Forças Armadas, pessoas ligadas ao ex-presidente da UDN adiantam que o que se verificou foi um contato entre Eduardo Gomes e o deputado federal Magalhães Pinto, no qual, definindo-se como um dos insufladores dos amotinados da aeronáutica, ele procurou fazer chegar até o presidente da república algumas "reivindicações" dos golpistas da FAB,

acrescenta-se que Eduardo Gomes estabeleceu ao chefe do governo, ao supremo magistrado da nação, ao presidente da república, as condições para que os ânimos na aeronáutica se "apaziguassem"41. Entre as exigências feitas, se acha a de o governo promover profunda alteração nos quadros de comando da FAB e mesmo no exército, onde o brigadeiro reclama o afastamento do ministro Teixeira Lott.42

A conjuntura favorecia esses rumores de golpe: crise econômica, denúncias de corrupção, "infiltração comunista" e os movimentos populares de reivindicação e protesto contra as difíceis condições de vida da população. O ano de 1959 começava sob o impacto de uma inflação de 22,60\% (IGP-DI da FGV), ocorrida no ano anterior e de um plano de estabilização econômica que impunha limites ao Plano de Metas. J uscelino entra em seu quarto e, pode-se dizer definitivo ano sob diversas pressões.

A classe média, mesmo sendo beneficiada pela euforia desenvolvimentista, com o aquecimento do mercado de trabalho para seus integrantes, também sentia na pele os efeitos deletérios da inflação galopante, percebendo claramente, pela desvalorização da moeda, que diminuía, sensivelmente, seu poder de compra. Era patente para a população que sentia no bolso os efeitos do modelo econômico colocado em prática por J uscelino que a economia estava no frigir dos ovos, beneficiando mesmo somente a classe média alta, os ricos e os muito ricos, os únicos com poder aquisitivo para consumir os caros bens de consumo importados e os que começavam a ser produzidos no país.

Face à tensão que começava a dominar o cenário político, no início desse ano, o governo ameaçou decretar Estado de Sítio. Diante de tais acontecimentos a contradição estava exposta, de um lado a articulação da sociedade civil através de varias entidades de caráter democrático principalmente as entidades ligadas ao movimento operário e rural, de outro o discurso "democrático" de abertura política e a prática repressiva do Estado autocrático. Como resultado desta contradição o controle efetivo dos movimentos populares era a negação da abertura política, pois segundo Maria de Aquino, nesse período foi o que mais se produziu de documentação na DOPS, revelando a vigilância intermitente do Estado frente a sociedade civil. A construção

4141 Recorte do jornal "Notícias de Hoje” de 28/ 12/ 1958. Anexo ao Relatório Reservado do DOPS 50.Z.09. Documento no 531.

42 idem 
dessa rede de informações nos bastidores pavimentou o caminho para a repressão que se praticava e do vindouro golpe de Estado de 1964 que se avizinhava.

Tendo esse "pano de fundo" como cenário, a conhecida frase de Ernani do Amaral Peixoto - "para J uscelino não existia 60, só 65" - define bem a atuação do então presidente da República nas eleições que iriam indicar o seu sucessor. Pode-se mesmo ir além e afirmar que, desde 1958, quando se realizaram eleições para o Legislativo e para os governos estaduais, J K já se movimentava no intuito de garantir sua volta ao governo do país. Como a possibilidade de reeleição em 1960 lhe era negada pela Constituição de 1946, a solução seria montar, com antecedência confortável, uma estratégia capaz de garantir em 1965 o objetivo sonhado. MOTTA (2009).

Segundo Marieta de Moraes Ferreira,

o presidente Juscelino manobrava desde o início do ano para que Juraci Magalhães, então governador da Bahia e presidente da UDN, fosse lançado à presidência da República como candidato de união nacional. Seria uma tentativa de estabilizar a vida política brasileira, permitindo à UDN, três vezes derrotada, chegar ao governo federal pelo caminho das urnas. Ao mesmo tempo, achando que J uraci faria um governo inepto devido principalmente à difícil situação econômica do país, J uscelino pensava garantir sua volta à presidência em 1965. (FERREIRA, 2009).

Concomitante às pretensões de Juscelino, a candidatura do general Lott era articulada por setores do PSD e PTB, até então sem o apoio de J ango e de consideráveis parcelas do seu partido que alegavam a falta de respaldo popular e a conseqüente fraqueza eleitoral do ministro da Guerra. Para complicar ainda mais a falta de consenso em torno da candidatura, as divergências entre os dois partidos a partir de 1959 se acentua tanto na condução da política econômica como também nas propostas políticas encabeçadas pelo PTB/ PSD frente à movimentação da classe trabalhadora.

Os questionamentos de Jango à política econômica e seus pronunciamentos sobre a necessidade de revisão na lei de remessa de lucros que disciplinasse o ingresso de capitais estrangeiros no país e de uma reforma bancária; seus encaminhamentos no sentido de uma reforma agrária que permitisse que alterasse as condições de acesso do trabalhador rural à terra, com a instituição de cooperativas ou algo semelhante, de redistribuição das rendas públicas para os estados mais pobres, de regulamentação do direito de greve, de abono à família rural; ou suas propostas de instituição do salário mínimo familiar; de reorganização da administração que iam deste o âmbito federal com a reorganização das delegacias regionais do Ministério do Trabalho e de criação da empresa, Centrais Elétricas Brasileiras (Eletrobrás), de reformas na previdência e 
formulação de diretrizes e bases para a educação, afastava cada vez mais a possibilidade de um consenso político partidário com o PSD.

A falta de consenso também se dava na relação do governo JK com os integrantes do PTB. Na medida do crescimento dos movimentos reivindicatórios da classe operária e da população, este responsabiliza seus pares pela ameaça que isto poderia representar à ordem estabelecida. Assustado com tais acontecimentos J uscelino convocou os ministros Henrique Lott (Guerra), Francisco Correia de Melo (Aeronáutica), J orge Matoso Maia (Marinha), Fernando Nóbrega (Trabalho) e Carlos Cirilo J únior (J ustiça) e autorizou a preparação de um plano de prevenção e repressão ao movimento liderado por Brizola e Jango. Emitiu ainda uma nota oficial onde criticava as "agitações" em curso.

Frente a estas sombrias perspectivas de movimentação social, nos bastidores do Serviço Secreto a denúncia de um complô sino-russo para as autoridades do alto escalão do exército contendo informações que comprovariam que a movimentação operária expressava o perigo da instauração de uma "república socialista" no país,

Exmo. Sr. General, em aditamento ao que tivemos a honra de expor a V.Excia., desejamos solicitar sua atenção para os seguintes fatos:1. a constante intensificação da propaganda comunista pelo rádio e a nova tática das rádios soviéticas e de Pequim, de estabelecer contatos diretos com os ouvintes e rádio amadores brasileiros, cujos nomes às vezes são até citados em programas especiais; 2 . a organização desde 1957 do "Clube de Rádio dos Amadores Revolucionários" em todos os países latino-americanos que formam uma eficiente rede de telecomunicações comunistas, mantendo contatos diretos com outros países; 3. o incremento das atividades desta rede de rádios-amadores em relação aos movimentos estudantis e grevistas. ${ }^{43}$

Esta correspondência entre uma pessoa indicada apenas diretor presidente, de nome Wladimir Pereira (não há referência no documento a qual instituição ele pertence) e o então chefe do Estado Maior do Exército encarregado do serviço de rádioescuta e rádio comunicações comunistas, o general Floriano de Lima Brayner ${ }^{44}$ observa-se como, a partir do diagnostico acima, estes ampliam suas formas de vigilância, no caso, solicitando reforços para a vigilância a rádios e aos meios de comunicação. $\mathrm{O}$ tom da mensagem denota um verdadeiro estado de guerra,

A impossibilidade para o serviço de Rádio-escuta SEI de seguir tão ampla operação com eficiência adequada; 5 . a necessidade de estender nosso serviço com a colaboração de certos postos de escuta e telecomunicações oficiais, como também com rádio-amadores

\footnotetext{
43 Correspondência de Wlademir Pereira endereçada ao general Floriano de Lima Brayner, datada de 20/04/ 1959. Relatório Reservado do DOPS. 50 Z.09. Documento no ${ }^{-560-A ~ e ~ B . ~}$

$44 \mathrm{O}$ general Floriano de Lima Brayer fora chefe do estado-maior da FEB durante o governo Vargas, até o fim da segunda guerra mundial.
} 
brasileiros de comprovada confiança, através de todo o território nacional; 6. solicitamos de V.Excia. a eventual indicação de nomes de militares e civis capazes de operar em escuta e telecomunicações dentro das normas de segurança e absoluto sigilo, necessários para não perturbar inoportunamente a rede comunista, conforme já aconteceu, o que traz graves prejuízos aos serviços de rádio-escuta e telecomunicações; 7. tratase de iniciar uma operação de envergadura capaz de enfrentar a ação simultânea, de dia e de noite, de centenas de estações operando livremente com o fito de orientar e sustentar as atividades comunistas. Consideramos que o perigo desta rede exige ser enfrentado com a urgente colaboração de todos. Com elevada consideração, aguardamos o pronunciamento de V.Excia. e nos subcrevemos, Atenciosamente. Vlademir Pereira (Diretor Presidente). ${ }^{45}$

Paralelamente, no interior da caserna, silenciosamente, a movimentação no sentido do isolamento de indivíduos que pudessem representar qualquer adesão ao janismo, janguismo, etc., começa a se processar e neste sentido alerta o censor em 1960, ao chefe do Serviço Secreto, que reinava intranqüilidade no seio da oficialidade, principalmente na Capital da República, em virtude de uma série de transferências levadas a efeito, especialmente, por questões políticas. Isto é: oficiais que externavam sua preferência por J ânio Quadros, mesmo entre colegas, eram denunciados e tempos depois, caso ocupassem postos chaves, estavam sendo transferidos.

No caso do capitão (informante), o mesmo tem mais de 10 anos de fronteira e, de acordo com o regulamento, pode reivindicar posto em unidades próximas a São Paulo. Contudo, por demonstrar simpatias à política do ex-governador paulista, foi agora transferido uma vez mais para a fronteira, tendo mesmo um coronel lhe informado que tal medida se prendia única e exclusivamente por ser simpático a Jânio Quadros. ${ }^{46}$

No caso especifico da aeronáutica, informava seu relatório, o foco de discordância com a eleição de J ango e J ânio era extremado, com propostas de adesão a golpes armados. Além disso, o informante já vislumbrava mudanças no ministério da guerra e no comando do 1o Exército, chamando a atenção para as articulações do Clube Militar, que como sempre era o termômetro dos ânimos militares,

diz o informante que Odílio Dennis será o futuro ministro da guerra e que o comandante do 10 Exército será o atual presidente do Clube Militar. Que, diante dessas irregularidades (transferências), foi solicitada uma sessão do Clube Militar, lista encabeçada por coronéis, sendo que o jornal carioca "Diário de Notícias" taxou todos os peticionários de comunistas. Que, brevemente haverá eleições no Clube Militar, prevendo-se acirrada campanha entre os simpatizantes de Jânio Quadros e Mal. Lott. E que, entre 15 capitães, foi levada a efeito uma prévia eleitoral, apurando-se que 13 votaram a favor de Jânio Quadros e 2 pró-Lott. 47

45 Correspondência de Wlademir Pereira endereçada ao general Floriano de Lima Brayner, datada de 20/04/ 1959. Relatório Reservado do DOPS. 50 Z.09. Documento no 560-A e B.

46 Informação Reservada 18/01/1960 -19- Setor "O.G.". Assuntos Gerais- Ambientes não especificados. Relatório Reservado Dossiê DOPS 50.Z.09. Documento № 564 página 2.

47 idem 
Lott representava segundo eles a infiltração comunista na tropa e se tornava imprescindível destruir a sua influência e a de seus aliados, principalmente no Clube Militar que desde 1952 estava nas mãos da "Cruzada Democrática" ou em outras palavras nas mãos da ESG. Nesse sentido a articulação de golpe ganha cada vez mais adeptos. Ainda segundo o informante o movimento grevista de dezembro daquele último ano estava indiretamente ligado ao levante da aeronáutica (referência ao levante da aeronáutica ocorrido em dezembro de 1959, conhecido como Levante de Aragarças) $^{48}$ no interior de Goiás. Isto e mais a conjuntura grevista de São Paulo, compunham os ingredientes para mais uma tentativa de golpe militar. Caso a greve em São Paulo tivesse êxito, ponderava ele, maior seria a repercussão naquela arma, sabendo-se mesmo que o ministro da guerra devia passar em revista um grupo de oficiais naquele dia, no Campo dos Afonsos, e que "estava combinado que todos sairiam de forma e tomariam lugar em seus aviões, não só em sinal de desrespeito ao ministro, como também de participação ativa no levante."49

Dessa maneira o confronto se manifesta, indo do desrespeito à hierarquia militar à perseguição ideológica nos quartéis, acirrando ainda mais o clima pré-eleitoral que já tomava conta da caserna com ares favoráveis ao político paulista J ânio Quadros. Apesar de não constar no Código Militar qualquer punição para os que simpatizassem com este ou aquele candidato à presidência da república, todos os que se enquadravam neste quesito foram afastados ou transferidos para locais onde não pudessem ter influência sobre a tropa. O informante do serviço secreto, nitidamente partidário de Lott, esclarece assim

que é do conhecimento do ministro da guerra que esses elementos, transferidos injustamente por causa de política, não tomarão qualquer atitude em caso de algum levante militar, em defesa de Lott, e suas unidades, na medida do possível, se manterão alheias a qualquer movimento. 50

Assim, se Lott era uma pedra do sapato da alta oficialidade o que dizer então de J oão Goulart e seu cunhado Leonel Brizola que eram considerados inimigos do Estado

\footnotetext{
48 Como o levante de Jacareacanga, o de Aragarças, em dezembro de 1959, teve duas motivações. Uma delas foi uma falseta de Jânio Quadros, que renunciou à sua candidatura à presidência da República - decepcionando, assim, militares e civis de direita. Outra foi a suspeita de que houvesse um golpe de esquerda em marcha, sob o comando de Leonel Brizola, a ser desencadeado a 15 de dezembro. Foi o que bastou para que, na noite do dia 2, oito oficiais armados se apoderassem de três aviões C-47 na base aérea do Galeão, no Rio de J aneiro, e voassem para Aragarças, às margens do rio Araguaia, em Goiás. O levante de Aragarças deu em nada, extinguiu-se sozinho em apenas dois dias, por falta de meios e porque $J$ ânio voltou atrás, renunciando à renúncia.

49 Informação Reservada 18/01/1960 -19- Setor "O.G.". Assuntos Gerais- Ambientes não especificados. Relatório Reservado Dossiê DOPS 50.Z.09. Documento oㅡ 564 página 2.

50 Informação Reservada 18/01/1960 -19- Setor "O.G.". Assuntos Gerais- Ambientes não especificados. Relatório Reservado Dossiê DOPS 50.Z.09. Documento no 564 página 3.
} 
e conseqüentemente os mais visados pelos segmentos reacionários, tanto civis quanto militares.

Após os incidentes que agitaram novamente a gestão de J uscelino, o seu vice J oão Goulart não teve êxito em seus objetivos, já que o governo manteve-se alheio às suas pretensões e Lott decidiu exonerar-se do cargo no dia 11 de fevereiro de 1960.

\section{Referências}

BENEVIDES, Maria Victoria de Mesquita. O governo Kubitschek: desenvolvimento econômico e estabilidade política. Rio deJ aneiro: Paz e Terra, 1979.

\section{. Dicionário Histórico-Biográfico Brasileiro: CPDOC Fundação Getúlio} Vargas. Rio de J aneiro, 2000. Disponível em:

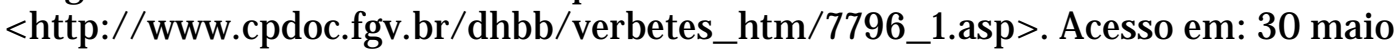
2009.

CARVALHO, J osé Murilo de. Forças Armadas e política no Brasil. Rio de J aneiro: ZAHAR, 2005.

CHASIN, J . A miséria brasileira: 1964-1994: do golpe militar à crise social. Santo André: Ad Hominem, 2000.

DREIFUSS, René Armand. 1964: A conquista do Estado: ação política, poder e golpe de classe. Petrópolis: Vozes, 2006.

FERREIRA, Marieta de Moraes. J oão Goulart. Verbete biográfico do CPCOC. Disponível em:<http:// www.cpdoc.fgv.br/dhbb/verbetes_htm/2412_5.asp>. Acesso em: 30 maio 2009.

GRYNSZPAN, Mario. O Brasil deJ K. Movimentos sociais no campo. Disponível em <http:// www.cpdoc.fgv.br/nav_jk/htm/O_Brasil_de_J K/ docs/Movimentos_sociais_ no_campo.gif >. Acesso em: 30 maio 2009.

MATTOS, Marcelo Badaró. Greves, sindicatos e repressão policial no Rio de Janeiro (1954-1964). Revista Brasileira de História, São Paulo, v.24, n. 47, 2004.

MOTTA, Marly. J K e as eleições presidenciais de 1960. Disponível em: <http://www.cpdoc.fgv.br/ nav_jk/htm/o_brasil_de_jk/J K_e_as_eleicoes_presidenci ais_de_1960.asp>. Acesso em: 30 maio 2009.

OLIVEIRA, Francisco de. Crítica à razão dualista: O ornitorrinco. São Paulo: Boitempo, 2003.

SARMENTO, Carlos Eduardo. O custo do desenvolvimentismo. Disponível em: <http:// www.cpdoc.fgv.br/nav_jk/htm/o_Brasil_de_J K/o_custo_do_desenvolviment ismo.asp >. Acesso em: 30 maio 2009.

WILLIAM, Wagner. O Soldado Absoluto: uma biografia do marechal Henrique Lott. Rio de J aneiro: Record, 2005.

Colaboração recebida 22/ 03/ 2010 em e aprovada em 08/ 12/ 2010. 